\title{
THE GEOLOGY OF THE BRAS D'OR LAKES, NOVA SCOTIA*
}

\author{
J. SHAW', D.J.W. PIPER, and R.B. TAYLOR \\ Geological Survey of Canada Atlantic \\ Bedford Institute of Oceanography \\ Box 1006, Dartmouth, Nova Scotia, B2Y 4 A2
}

\begin{abstract}
The evolution of the Bras d'Or Lakes since the retreat of the last ice sheets c. $15 \mathrm{ka}$ (thousands of radiocarbon years before present, where present is defined as 1950) is inferred from multibeam bathymetry, seismic reflection profiles, and sediment cores. The thickness of stratified sediment in the Lakes overlying glacial till shows that there was a step-like retreat of ice towards a late ice centre in the western part of the Bras d'Or Lakes. As ice retreated, a lake formed in the area of the modern Bras d'Or Lakes and probably drained through Little Bras d'Or Channel. Ice retreat and sea level change on the continental shelf off south-eastern Cape Breton are inferred from multibeam bathymetry that shows proglacial subaerial river channels and suggests that sea level was perhaps $50 \mathrm{~m}$ lower than present about $15 \mathrm{ka}$. Relative sea level appears to have risen subsequently, so that marine conditions existed in Bras d'Or Lakes basin at 10 to $9 \mathrm{ka}$. Sea level may have risen to $-15 \mathrm{~m}$ (below modern sea level) before falling again in the early Holocene. This falling early Holocene relative sea level resulted in the creation of freshwater lakes, with a prominent erosion surface at $-25 \mathrm{~m}$ marking the lake level in some areas. Rising sea level then resulted in a return to marine conditions in the Lakes by 4 to 5 ka.
\end{abstract}

L'évolution des lacs Bras d'Or depuis le retrait des dernières nappes glaciaires il y a 15000 ans se révèle par la bathymétrie multifaisceaux, les profils de réflexion sismique et les carottes de sédiments. L'épaisseur des sédiments stratifiés dans le till sus-jacent des lacs démontre qu'il y a eu un retrait en escaliers des glaces vers un centre fini-glaciaire situé dans la partie occidentale des lacs Bras d'Or. Les eaux, libérées lors du retrait des glaces, s'échappèrent probablement via le canal du Little Bras d'Or pour former un lac dans le lit actuel des lacs Bras d'Or. Le retrait des glaces et les changements du niveau de la mer sur la plateforme continentale au sud-est de Cap-Breton sont mis en évidence par la bathymétrie multifaisceaux, qui montre des lits de rivière sub-aériens proglaciaires et indique que le niveau de la mer se trouvait peut-être à $50 \mathrm{~m}$ plus bas qu'aujourd'hui il y a environ 15 milles d'années. La hausse du niveau de la mer depuis cette époque a provoqué l'inondation des lacs Bras d'Or ancestraux il y a de 9 à 10 milles d'années, et le niveau des eaux aurait atteint $-15 \mathrm{~m}$ avant de chuter au début de l'Holocène. Cette chute relative du début de l'Holocène a résulté en la création de lacs pour une seconde fois, avec une importante surface d'érosion à - 25 m qui marque le niveau des eaux dans certaines zones. Ces lacs ont été finalement inondés par la mer il y a de 4 à 5 milles d'années.

\section{Introduction}

The Bras d'Or Lakes are a series of low-salinity lakes filling deep depressions in central Cape Breton Island (Fig 1). The lake system consists of Bras d'Or Lake in the south (Fig 2), which includes West Bay, East Bay, Denys Basin, and St. Peter's Inlet. Barra Strait provides the connection to the northern part of the Lakes, which include the Great Bras d'Or Channel, St. Andrew's Channel, St. Patrick's Channel, Little Bras d'Or Channel, and Whycocomagh Bay. The Bras d'Or Lakes are connected to the Atlantic Ocean at three locations: Great Bras d'Or Channel, with a minimum depth of about $8 \mathrm{~m}$; Little Bras d'Or Channel, a 6-m-deep sinuous estuary; and the canal and boat locks at St. Peter's Inlet.

In this paper, we present and synthesize information on the geological history of the Lakes, focusing on the past ten to fifteen thousand years, during which period the last

\footnotetext{
* Geological Survey of Canada contribution 2001110.

${ }^{1}$ Author to whom correspondence should be addressed
} 


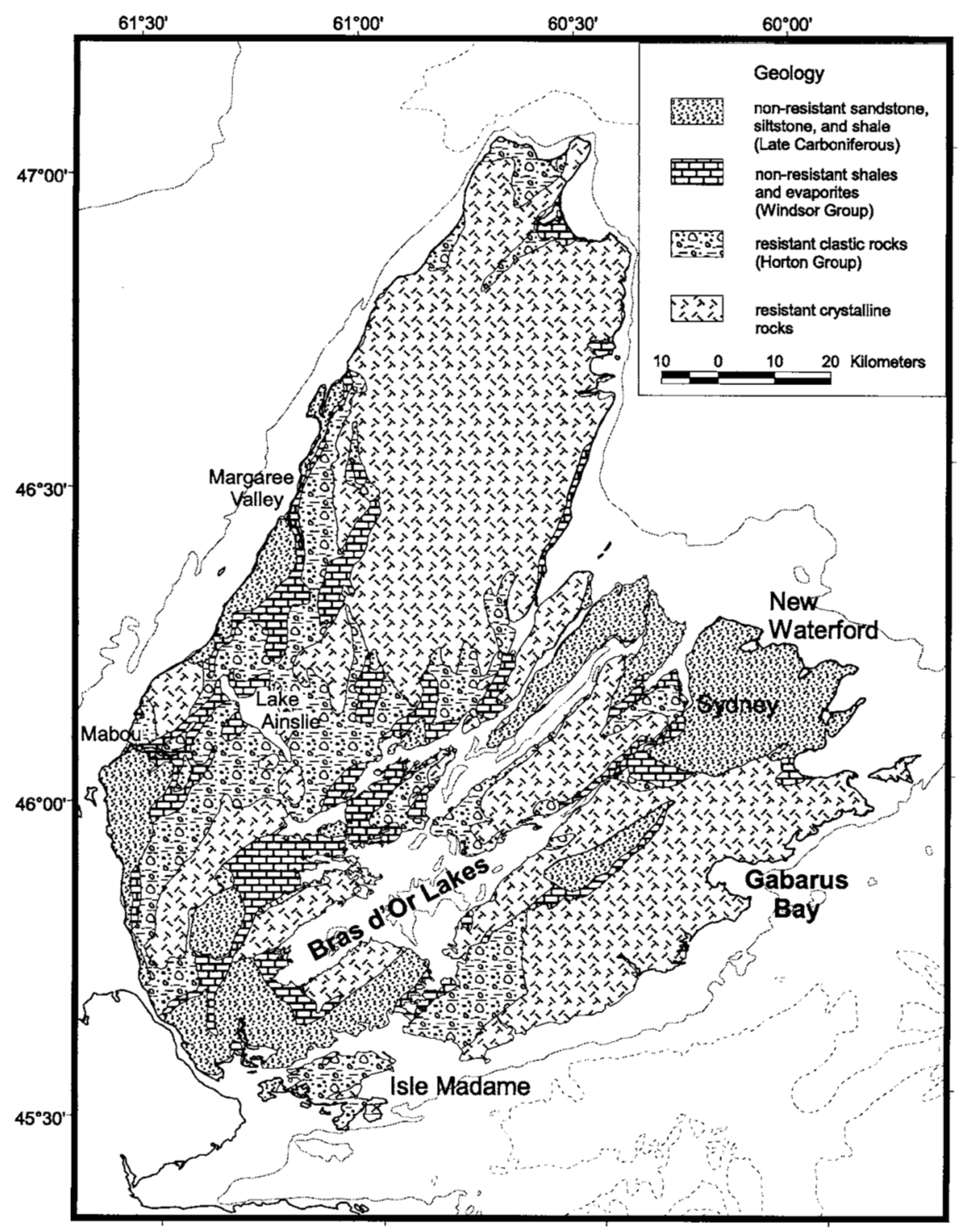

Fig 1 Map of Cape Breton, showing location of the Bras d'Or Lakes and the bedrock geology of Cape Breton Island, Nova Scotia (simplified from Keppie, 2000). 


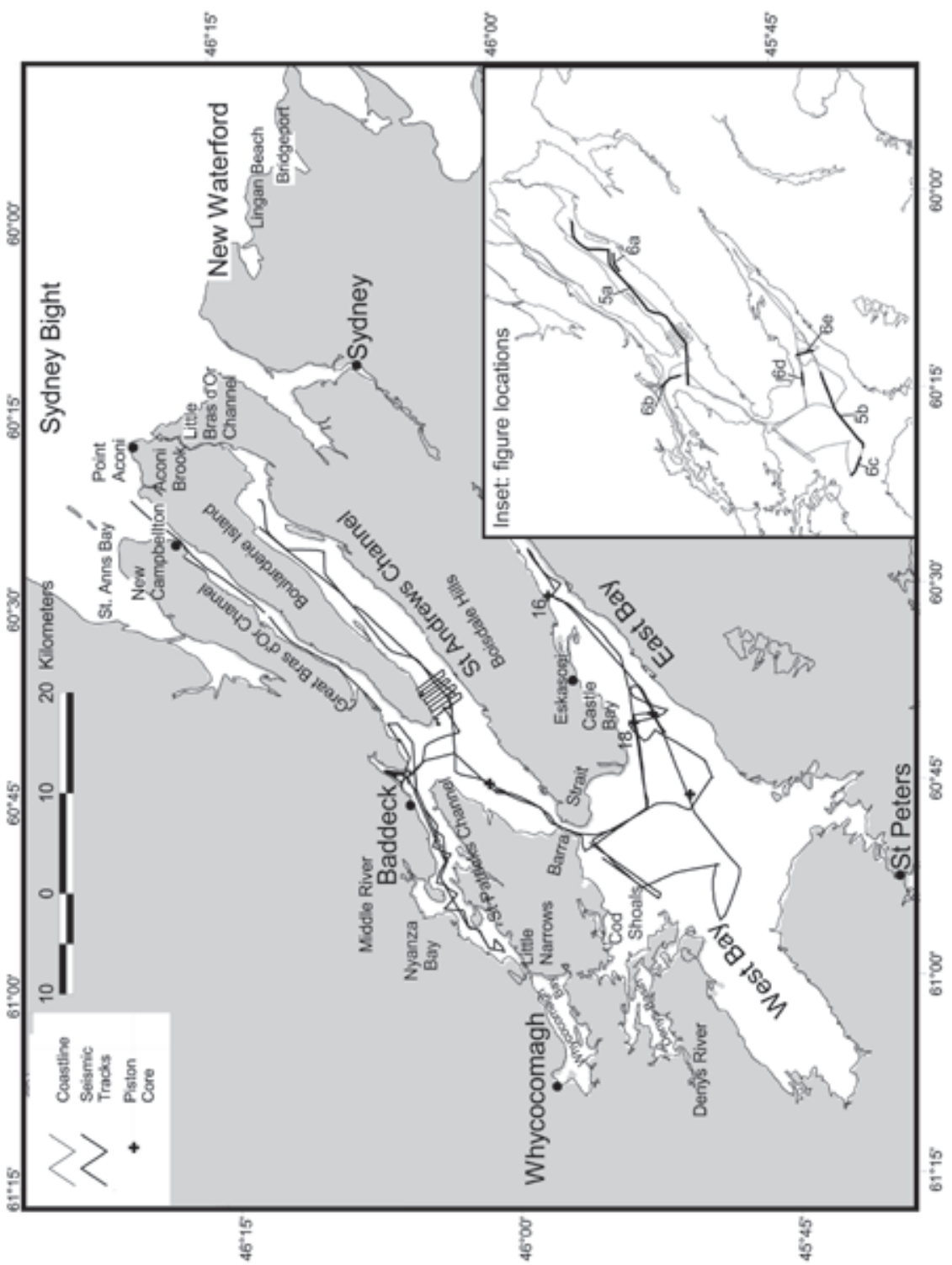

Fig 2 Map showing ship's tracks for cruise 96-155 (CCGS Hart) and tracks and core sites for cruise 85-036 (CSS Dawson). Cores 16 and 18 (discussed in the text) are numbered. The map also shows locations of seismic profiles illustrated in figures. The bathymetric contours are from Canadian Hydrographic Service field sheets summarized in Canadian Hydrographic Service (1990, 1991, 1993). 
ice sheets retreated from Cape Breton Island. Our information dealing with the marine geology of the Bras d'Or Lakes comes primarily from seismic surveys and sediment cores collected from CSS Dawson in 1985 (cruise 85-036) and the CCGS J.L. Hart in 1996 (cruise 96-155), together with information from multibeam bathymetry surveys on the continental shelf off southeastern Cape Breton Island.

\section{EVOLUTION OF LAKES \\ AND SEA LEVEL HISTORY}

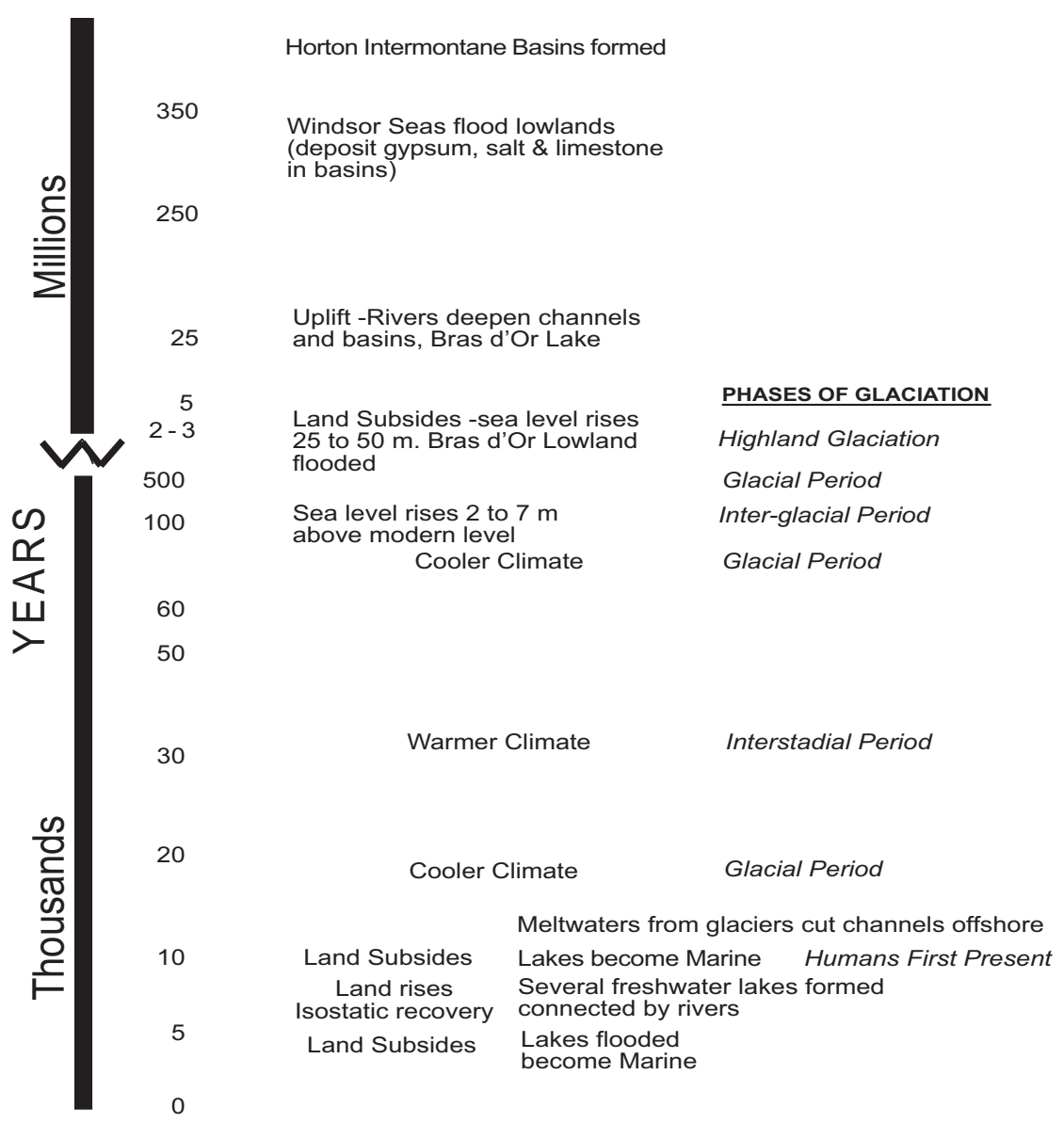

Fig 3 Geological timeline showing evolution of the bedrock geology and the phases of glaciation around the Bras d'Or Lakes. (Modified from Roland 1982 and Grant 1994).

Bedrock geology The lakes and lake basins are localised over 'weak rock lowlands' (see summary in Grant, 1994). Widespread rifting and regional tectonic plate movements in southern Cape Breton Island, at the end of the Devonian period some 360 
million years ago, formed a series of small, fault-bounded basins between highlands of resistant crystalline rocks (Calder, 1998). Gravel and sand were deposited as alluvial fans at the edges of basins and in river systems and lakes on the basin floors. Lithification of these sediments produced the resistant conglomerates and sandstones of the Horton Group (Fig 1). Circa 340 million years ago the sea flooded many low areas in Atlantic Canada, including the basins of southern Cape Breton Island, depositing a thick sequence of fine grained muds and evaporites, including gypsum, anhydrite, and salt (Fig 3). The Windsor Group rocks, as they are known, underlie most of the Bras d'Or Lakes. Younger coal-bearing rocks of the Sydney Basin were subsequently deposited over much of southern Cape Breton Island.

Cape Breton Island has been slowly uplifted in the past 230 million years, largely as a result of opening of the modern Atlantic Ocean. Most of the original sedimentary rocks of Carboniferous age have been removed by gradual erosion over this period (Ryan and Zentilli, 1993), but Horton and Windsor Group rocks are still preserved in their original basins around the Bras d'Or Lakes. The Windsor Group rocks are particularly soft and thus easily eroded. This was particularly the case during the Tertiary, when rivers deepened their courses and Bras d'Or Lake and Great Bras d'Or Channel were carved out between the uplands of more resistant crystalline rocks. The resistant blocks form plateaus with elevations that increase from southeast to northwest across Cape Breton Island.

Outcrops of Windsor rocks are observed today scattered through the Bras d'Or Lakes basin, some as distinctive white shore cliffs. The dissolution of evaporites produces distinctive karst topography in the Bras d'Or Lakes basin. For example, sinkholes occur in coastal areas near Barra Strait, and are also visible in unpublished multibeam bathymetry imagery from there. The presence of these deposits may also be responsible for the extremely deep waters observed in St. Andrew's Channel. Boehner (1985) discovered through drilling on Boularderie Island that the deep areas coincide with projected outcrops of rock salt at the base of the Windsor Group. These deposits would have dissolved quickly if folding and fracturing allowed ground water to contact the salt. Full development of the deep-water depressions may have occurred in recent geologic times; the history of these features is not clear.

Regional Quaternary geology Two to three million years ago, sea level in southern Cape Breton Island was probably 25 to $50 \mathrm{~m}$ higher than now, which would have flooded the Bras d'Or Lakes basin (Roland, 1982); Roland also suggested that the coastal shelves stretching northward from St. Ann's Bay along the eastern coast of Cape Breton Island, and from Great Bras d'Or Channel to Nyanza Bay, are the products of these higher seas. The climate progressively deteriorated during the following Quaternary period, with highland glaciers first forming perhaps 1.6 million years ago and periods of widespread continental glaciation starting about 0.5 million years ago (Piper et al., 1994). Between glacial periods, each of which lasted many tens of thousands of years, were interglacial periods with climates similar to today. During the last interglacial period, the Sangamon Interglacial about 125,000 years BP, sea level was 2-7 m higher, forming a fossil intertidal wave cut bench along many Atlantic shores and the north shore of East Bay (Grant, 1994). The location of the interglacial paleoshoreline would not have differed much from the present shore along steeper upland areas, but would have reached several kilometres inland along lowland areas. Lake Ainslie Basin, Margaree Valley and possibly Mabou Estuary (Fig 1) were arms of the sea, which may have connected to the Bras d'Or Basin (Grant 1994). The Bras d'Or Basin would have been larger as the bordering lowlands were flooded and the adjacent uplands, such as the Boisdale Hills (Fig 2), may have been islands. Two additional 
marine connections at St. Peter's and through East Bay to Sydney may have existed, and the Little Bras d'Or Channel was wider (Grant, 1994).

On land, most fresh erosional features and glacial deposits were formed during the last (Wisconsinan) glaciation, from about 75 to $10 \mathrm{ka}$ ( $1 \mathrm{ka}=1000$ years). Eight phases of glaciation are distinguished by Grant (1994) on the basis of studies on land, although there is debate over the details and the timing, particularly of the earlier phases (e.g., Stea et al. 1998). During Phase A (62 to $47 \mathrm{ka}$ ) local ice spread into the lowlands from the ice cap on the highlands. There remains little depositional or erosional evidence of this event.

Phase B was a major glacial event during which foreign ice from the west spread eastward across Cape Breton Island. The direction of ice movement coincided with the orientation of valleys in the Bras d'Or Basin, facilitating the scouring of the weak underlying rocks. The ice flow is also thought to have blocked drainage as it advanced into East Bay, changing the saltwater arm into a proglacial lake called Lake Cameron about $62 \mathrm{ka}$. The timing is based on pollen studies of the nearby Castle Bay silts, deposited $20 \mathrm{~m}$ above modern sea level (deVernal and Mott, 1986; deVernal et al. 1986).

Glacial Phase $C$ involved regional ice sheets flowing southeast over Cape Breton Island but there is little evidence of this phase in the Bras $d^{\prime} O r$ Basin. It is suggested the regional ice overrode a pre-existing ice mass, which covered the area during the early part of phase C. Indirect evidence of climatic warming and a glacial recession between ice phases $\mathrm{C}$ and $\mathrm{D}$ is provided by the occurrence of shell and wood samples which varied in age from 47 to $32 \mathrm{ka}$, and a mastodon femur sampled from a farm along Middle River which yielded ages around 32 ka (Grant, 1994).

Glacial ice in phase D flowed north across the southern lowlands from an ice centre south of Cape Breton Island. The ice was responsible for reshaping drumlin fields in the southern lowland and for depositing the distinctive bright red fossiliferous till containing marine shell fragments. During phase D there may also have been ice spreading outward from the highlands and intersecting the main northward flow of ice. Grant (1994) argued that phase D was of Mid-Wisconsinan age, but more recently Stea et al. (1998) put a strong case that the coeval northward flow in Nova Scotia was Late Wisconsinan age. The implication is that all the subsequent phases described here are younger.

Phase E was the establishment of an island centred ice cap from 15 to $13 \mathrm{ka}$ (Fig 4), which is recorded by southeast trending striations and drift south of the Bras d'Or Lakes. There is also a patchy veneer of locally derived stony till from the crystalline uplands. The age of this phase given in Grant (1994) was based on Stea et al. (1992) estimates. Presumably it was the meltwater from this ice mass that cut channels several kilometres off eastern Cape Breton to modern water depths of roughly 40-50 m.

As the inland ice shrank into the Bras d'Or Lakes basin, ice in Phase F impinged on the Gulf of St. Lawrence shore, damming several valleys (including Ainslie and Margaree) with kame moraines (Grant 1994). Grant argued that phase F predated 10-11 ka.

Phase $G$ saw the continued retreat of Bras d'Or ice into the basin as recorded by ice-marginal moraines and meltwater channels (Fig 4). This ice left moraines north of Whycocomagh and north of Nyanza Bay along the northern basin and at some stage built the large submerged ridge across St. Ann's Bay and a moraine at New Campbellton along the Great Bras d'Or Channel (Grant 1994). As the ice mass shrank and possibly re-advanced in the period 11-10 ka, a series of ice dammed lakes formed in the west, including Denys Basin. Surface organics dated at a number of sites suggested to Grant 


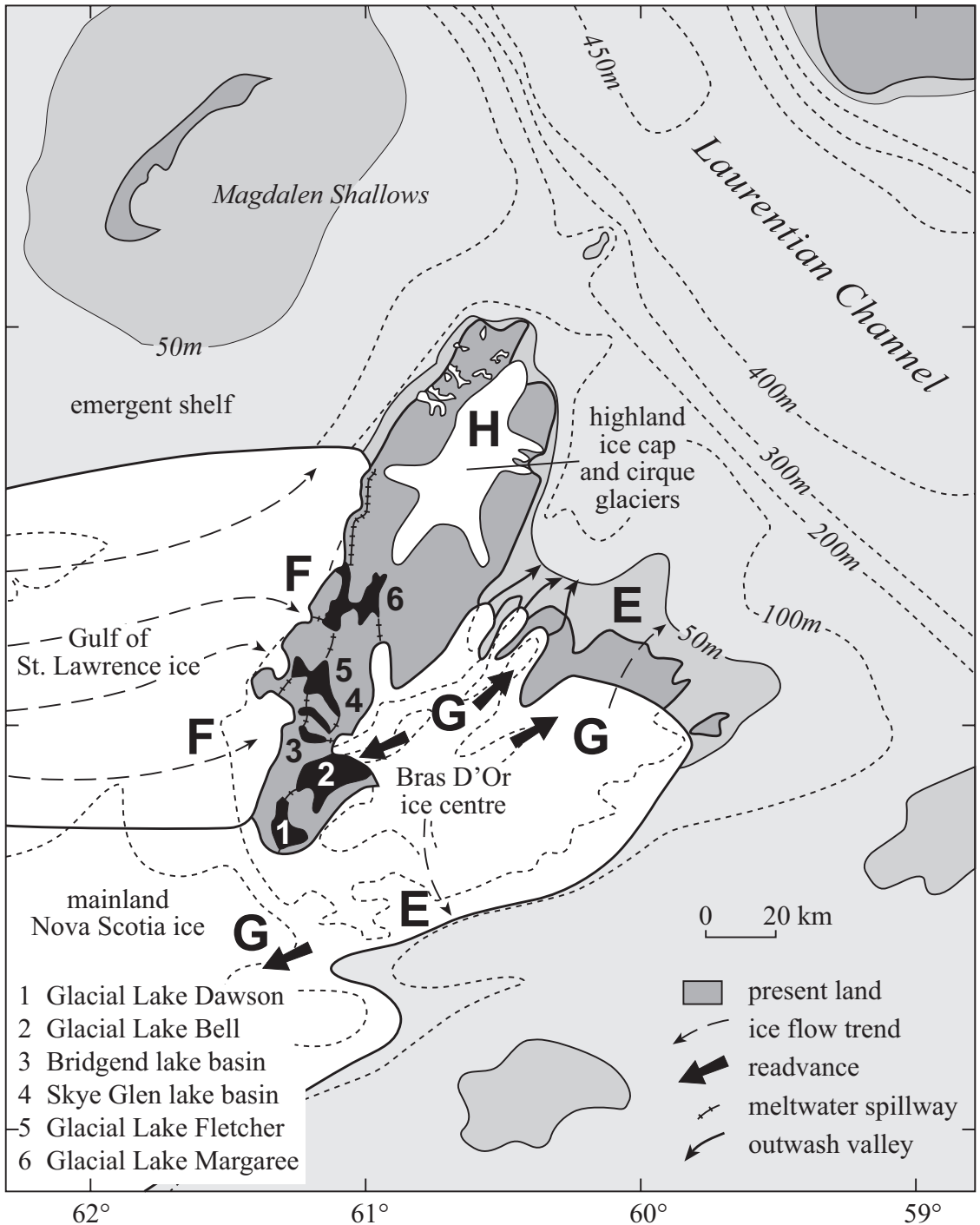

Fig 4 The final glacial events in the Bras d'Or Lakes area, adapted from Fig 114 of Grant (1994). Phase E is the establishment of an island-centred ice cap. In phase F, Gulf of St. Lawrence ice impinges on the west coast. Phase G is concentric retreatal flow and local advance of lowland ice. Phase $\mathrm{H}$ represents radial flow and concentric retreat of the highlands remnant ice cap. Areas between modern sea level and the $-50 \mathrm{~m}$ isobath have an intermediate shading; these areas were emergent during stage G. 
that ice had retreated to the confines of the Bras d'Or Lakes by ca. $10 \mathrm{ka}$ (Mott and Stea, 1993; Miller 1997). Phase $\mathrm{H}$ involved a local independent ice cap on the highlands that did not impact the Bras d'Or Lakes directly but may have produced valley glaciers which extended some distance down the Middle and Baddeck Valleys.

There is a problem reconciling the scenario outlined above with the more recent work of Stea et al. (1998) and Stea and Mott (1998) who date Grant's Phase E at 12.5 - 11.0 ka. Sections where glaciolacustrine clay overlies peat conclusively show that glacial lake development from Gulf ice postdated $10.8 \mathrm{ka}$, suggesting that Phase $\mathrm{F}$ could be equated with the Younger Dryas period (c. 11-10 ka). In fact, for the period 11-10 ka, Gulf ice was impinging on the west coast, a small cap of ice existed in southwest Cape Breton, and a larger residual cap on the Cape Breton Highlands. It is likely therefore, that the events in Grant's phases E - G occurred in the period 12.5 $-10 \mathrm{ka}$. Phase $\mathrm{H}$ - the ice cap in the highlands - may have been later.

\section{Quaternary deposits of the Bras d'Or Lakes}

Seismic reflection profiles and piston cores from the Bras d'Or Lakes collected on cruise 85-036 (CSS Dawson, Fig 2) provide information on the late Quaternary history of the Lakes. The longest cores from the Lakes penetrate only the Holocene postglacial sequence (last $10^{4}$ years), so that the character of Pleistocene glacial and late glacial

(a)

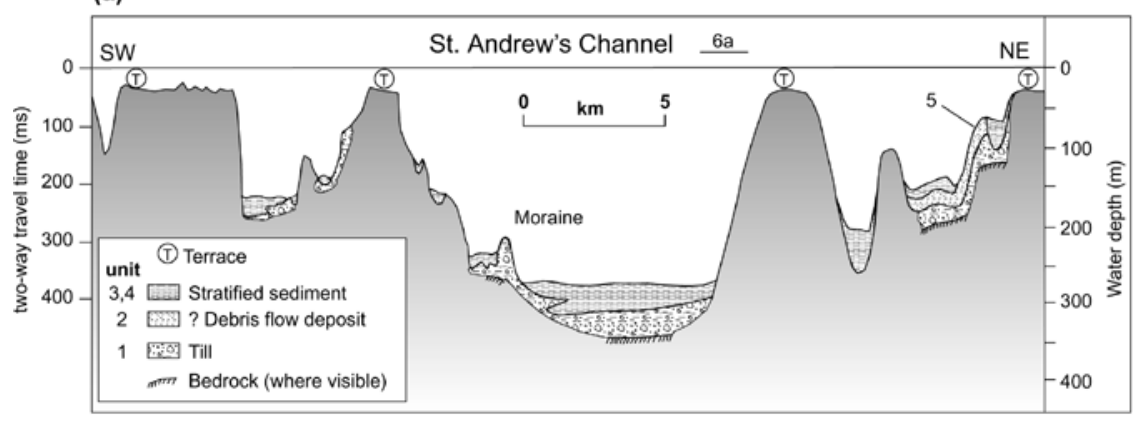

(b)

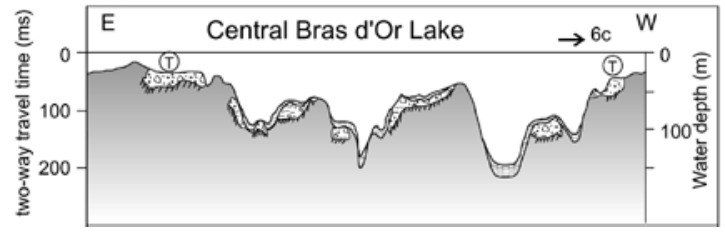

Fig 5 Line drawing of air gun profile (a) along St. Andrew's Channel and (b) at the eastern end of West Bay, showing distribution of bedrock (where visible), till and younger sediments. Refer to Fig 2 (inset) for line location. 
sediments must be inferred from seismic profiles by comparison with better-known deposits on the continental shelf (King and Fader, 1986). The sequence of acoustic units recognized in the Bras d'Or Lakes (Lynch 1995) is summarized in Table I and in Fig 5.

Table I Seismostratigraphic sequence in the Bras d'Or Lakes (modified from Lynch, 1995).

Unit 4. Surficial muds, Holocene age.

Facies $1 \mathrm{~A}$ - stratified (near surface)

Facies 1B - amorphous transparent (St. Andrew's Channel \& St. Patrick's Channel)

Facies $1 \mathrm{C}$ - weakly stratified

Unit 3. Proglacial sediments (Emerald Silt equivalent on Scotian Shelf)

Unit 2. Incoherent to weakly stratified.

Facies $3 \mathrm{a}$ - thick sequence filling valleys, with positive surface relief

Facies $3 b$ - thin drape over till

Unit $1 \quad$ Glacial till

Bedrock

Unit 1 overlies bedrock over most of the floor of the Bras d'Or Lakes (e.g., Figs. $5 a, 6 d)$, but is absent in northern Great Bras d'Or Channel. Airgun seismic profiles show that Unit 1 is typically $30 \mathrm{~m}$ thick in central Bras d'Or Lake (Fig 5b), with greater thicknesses where drumlins are developed (Fig 6c). Drumlins are also recognised in East Bay (Fig 6e). In St. Andrew's Channel, Unit 1 is 30-40 m thick on the deep channel floor (Fig 5a). Unit 1 is interpreted as glacial diamict (or till).

Unit 2 (Table I) consists of sediment with weak acoustic stratification that forms a drape a few metres thick over parts of the Unit 1 (Fig 6e) and resembles Facies C of Emerald Silt described by King and Fader (1986) from the Scotian Shelf. In some basins Unit 2 is tens of metres thick, with positive surface relief (Fig 6e), and has the acoustic character typical of muddy debris flow deposits. Unit 2 was deposited very close to a glacial ice margin.

Unit 3 (Table I) consists of acoustically well-stratified sediment that tends to drape over pre-existing topography (Fig 6). The acoustic character closely resembles that of the Emerald Silt (Facies A and B) of the Scotian Shelf (King and Fader 1986), which is a silty mud deposited from proglacial sediment plumes. In central Bras d'Or Lake, Unit 3 is typically about $5 \mathrm{~m}$ thick and generally thins towards shallower water. This suggests deposition from proglacial plumes distant from the high sedimentation rates found near the ice margin, with the upslope thinning resulting from slight winnowing by waves in shallower water. Rapid local thickening is found near Baddeck (Fig 6b), suggesting proximity to an ice margin here.

Unit 3 is either absent or $<2 \mathrm{~m}$ thick in north-eastern West Bay (Fig 6c), suggesting that there may have been later stagnant ice in this area. In contrast, much thicker sequences of Unit 3 are found in the north-eastern parts of East Bay, St. Andrew's Channel (Fig 6a) and Great Bras d'Or Channel, indicating a prolonged period of proglacial deposition, presumably during the late phase G of Grant (1994). Abrupt changes in thickness of this unit on either side of a bedrock ridge suggests that this ridge represents the site of a stable ice margin, so that stratified sediment to the northeast was 

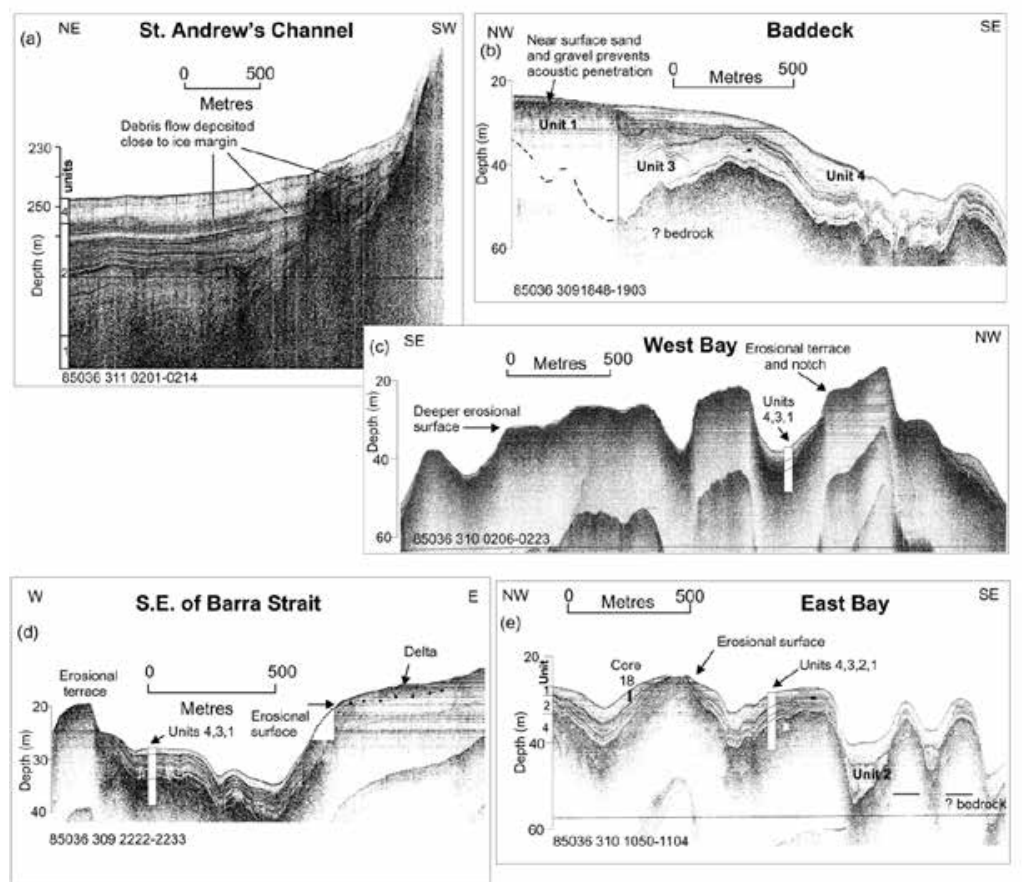

Fig 6 Huntec DTS boomer profiles showing late glacial features of the Bras d'Or Lakes: (a) proglacial sediments adjacent to southern margin of St. Andrew's Channel; (b) ice-margin sediments of Unit 3 that thicken rapidly northward towards Baddeck; (c) thin or absent Unit 2 in West Bay and the smooth erosion surfaces at -29 m and -22 m; (d) erosion surface at -19 m and delta progradation from -16 m, southeast of Barra Strait; (e) erosion surface and location of core 85036-18 in East Bay (bedrock interpreted from air gun seismic profile). Location of lines on Fig 2 (inset).

probably deposited at the same time as till to the southwest (Fig 5a). Seaward of this ridge, Unit 3 is interbedded with acoustically incoherent wedges of Unit 2, interpreted as proglacial debris flows (Fig 6a). In some areas where unit 3 is thick, acoustic penetration is masked by shallow gas.

Unit 3 is truncated by a widespread erosion surface in water depths of $<50 \mathrm{~m}$, with strong planation at depths of about 20 - 25 m (Fig 6c). A small delta has prograded across this erosion surface south of Barra Strait (Fig 6d), with topsets indicating a water level as shallow as $16.5 \mathrm{~m}$, apparently under conditions of falling water level. In West Bay, a smooth planar surface at a water depth of $21 \mathrm{~m}$ with an erosional notch (Fig 6c) contrasts with rougher seabed in shallower water.

Unit 4 (Table I) consists of mud with variable degrees of acoustic stratification. The unit partially drapes over existing topography, but is typically twice as thick in basins as over ridges. Its thickness appears strongly influenced by tidal currents between Great Bras d'Or Channel and Barra Strait. In central St. Andrew's Channel, a 10-m thick 


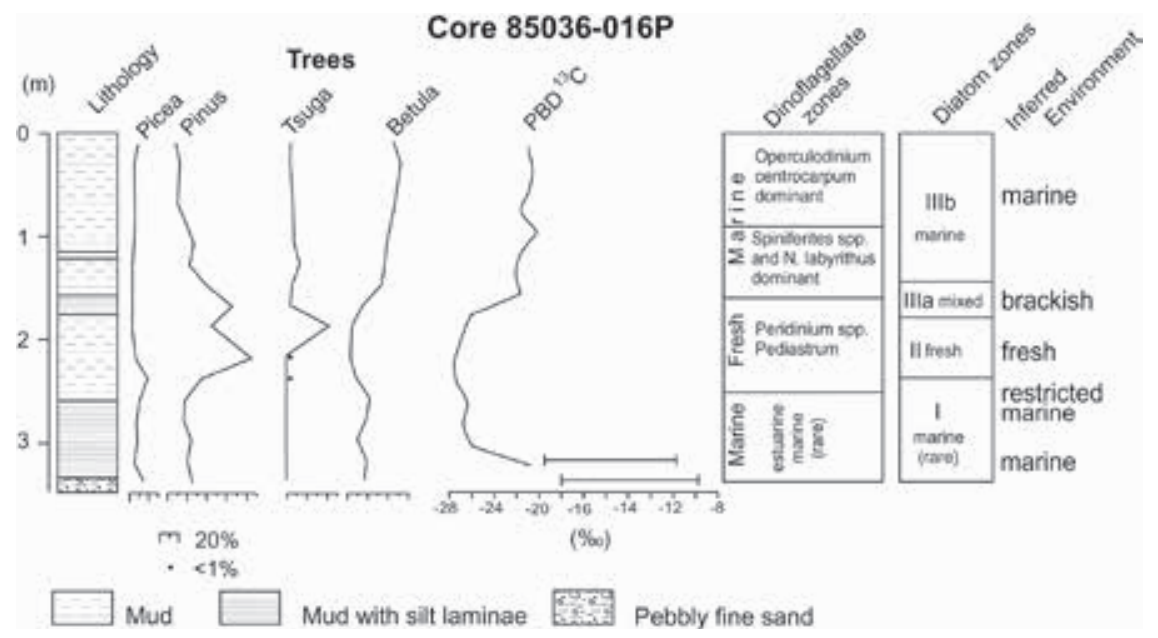

Fig 7 Summary of piston core 85-036-016P showing lithology, biostratigraphy (from de Vernal and Jetté 1987 and Lortie 1987), $\delta^{13}$ C (Hillaire-Marcel 1987) and interpreted age and environmental history. The tree pollen spectra illustrated here are spruce (Picea), pine (Pinus), hemlock (Tsuga) and birch (Betula). Dinoflagellates and diatoms are unicellular algae. The setting of core 16 is similar to that of core 18, illustrated in Fig $6 \mathrm{e}$.

debris flow deposit (unit 2, recognized from its rough surface relief and acoustically incoherent character) occurs at the base of Unit 4 (Fig 6a).

Piston cores 16 and 18 from East Bay (Figs 2; 6e) both penetrate the entire thickness of Unit 4 and were stopped by a bed of sand and gravel (clasts $<1 \mathrm{~cm}$ ). Both core sites are located about $5 \mathrm{~m}$ deeper than a nearby erosional terrace. The basal sand and gravel are interpreted as sediment swept off the erosional terrace in the littoral zone and corresponds to a strong reflection in seismic reflection profiles (Fig 6e). Overlying sediment consists principally of mud, in some places with many silty laminae. Detailed biostratigraphic studies reveal three different depositional environments within Unit 4. The basal metre of sediment in core 16 contains sparse marine dinoflagellates (de Vernal and Jetté 1987) and very rare marine diatoms (Lortie 1987) (Fig 7). Although the sparse flora might be interpreted as reworked older material, the marine character of this interval is confirmed by isotopic analysis of organic carbon (Hillaire-Marcel, 1987). It is overlain by $1 \mathrm{~m}$ of sediment with mostly cold freshwater diatoms and freshwater dinoflagellate cysts. That layer is overlain by $1.5 \mathrm{~m}$ containing a rich variety of marine diatoms and dinoflagellate cysts, with evidence of an upward decrease in salinity and temperature. The transition between freshwater and marine diatom floras is marked by a mixed assemblage of freshwater, brackish water and marine species. No material suitable for radiocarbon dating has been found in the cores. Correlation of the tree pollen assemblages in Core 16 with the regional palynostratigraphy of Livingstone (1968) suggests that the basal marine interval dates from the Picea and Betula zone at 10 to $9 \mathrm{ka}$, the lacustrine interval from $9 \mathrm{ka}$ to $4-5 \mathrm{ka}$, and the upper marine interval is younger than 4-5 ka (de Vernal and Jetté 1987). 


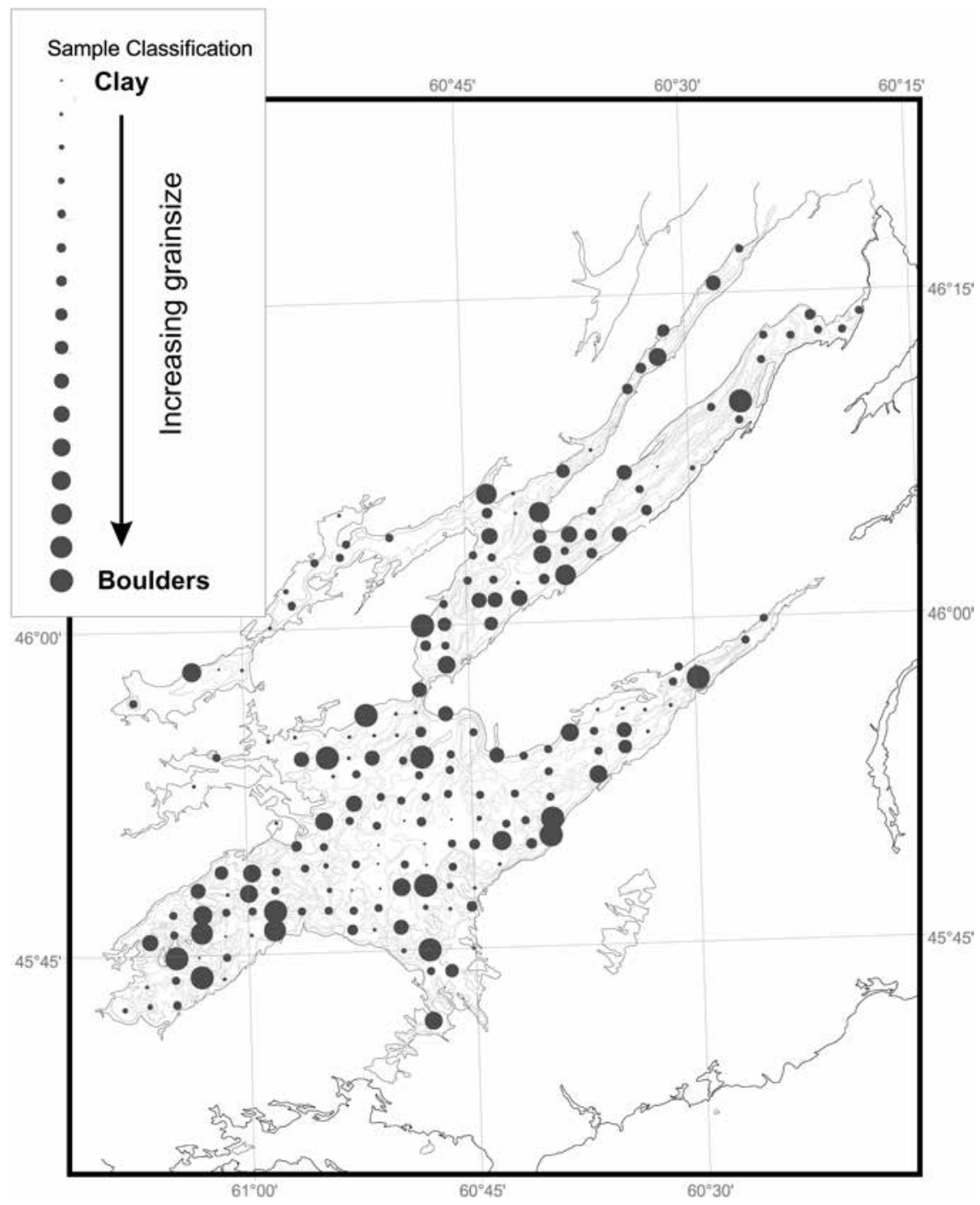

Fig 8 Map of the Bras d'Or Lakes showing generalized sediment grain size at sampling sites (modified from Vilks 1967). 


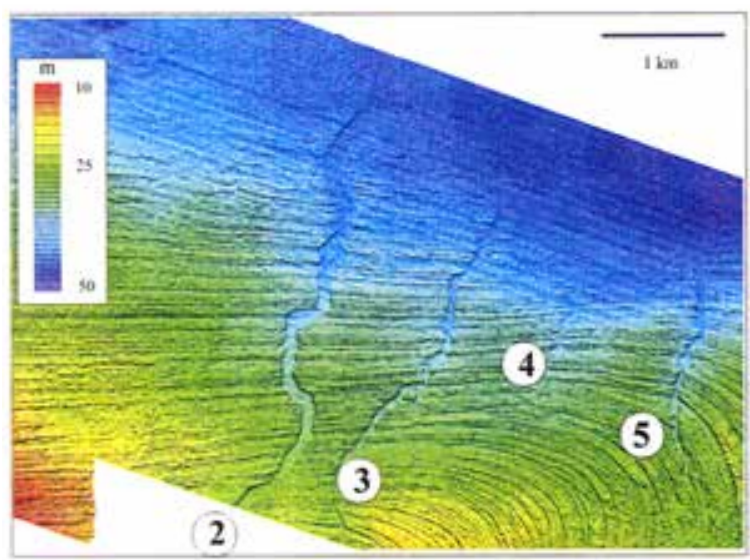

Fig 9 Coloured shaded-relief multibeam image of submerged channels (numbered) off the coast of Cape Breton in the New Waterford area. Image courtesy of R.C. Courtney (Geological Survey of Canada - Atlantic). Location of channels shown in Fig 13.

Surficial sediment distribution in the Bras d'Or Lakes (Fig 8) was described by Vilks (1967) on the basis of some 100 grab samples. This information is augmented by later bottom samples from cruise 85-036 and by sidescan sonar data reported by Cooper (1993). Deeper areas of the Lakes are floored with mud, except for sands in some areas flushed by tidal currents. More exposed shallow areas of the western part of the Lakes are commonly floored by gravelly sandy mud, resulting from erosion of till.

\section{Postglacial changes in lake level}

We have interpreted the seismic reflection profiles and cores in terms of changes in lake level and salinity. Other evidence augments these findings. Grant (1994) reported submerged channels off the northeast coast of Cape Breton, the largest of which appeared to be extensions of Aconi Brook and Little Bras d'Or Channel. They reached depths of 40-50 m, and were thought to be coeval with the later stages of the Bras d'Or Ice Cap. Wang and Piper (1982) found truncated till surfaces down to $-50 \mathrm{~m}$ in (i.e. below present sea level) Gabarus Bay, on the south coast of Cape Breton Island; below this depth, till surfaces were unmodified. They concluded that the maximum early Holocene lowering of relative sea level was $50 \mathrm{~m}$.

However, there are some apparent contradictions in published interpretations. Hillaire-Marcel (1987) and de Vernal and Jetté (1987), on the one hand, require that relative sea level was high before 9-10 ka, and that it fell early in the Holocene epoch. On the other hand, Grant (1994) believed that meltwater from late-glacial ice drained east across an emergent coastal plain that extended to the modern $50 \mathrm{~m}$ isobath, thus requiring that relative sea level was low in late glacial times. We examine sea-floor morphological evidence that helps to resolve this contradiction.

Submerged river valleys and erosion surfaces outside the Bras d'Or Lakes. Multibeam bathymetry surveys of the sea floor off New Waterford (Fig 1) show 5 steep-sided, flatbottomed channels, 2-3 m deep, four of which are illustrated in Fig 9. Long-profiles 


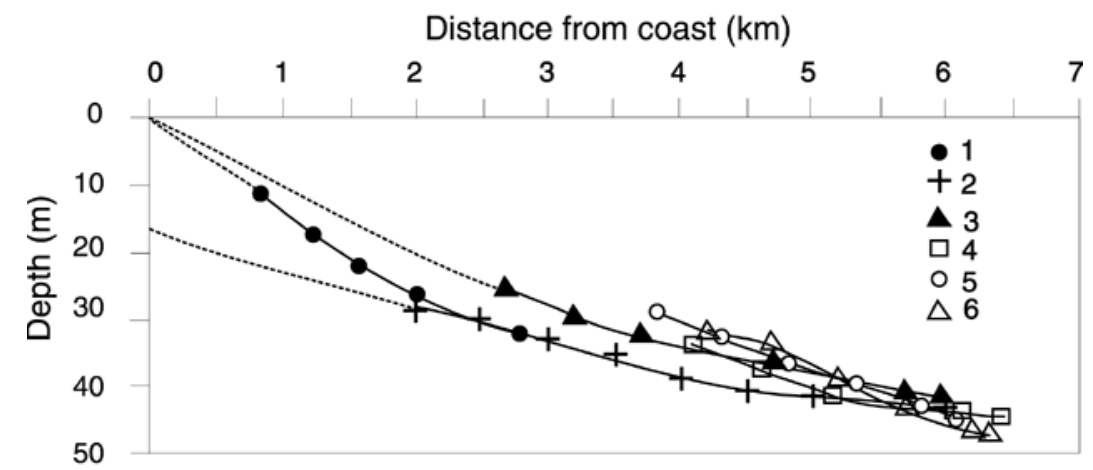

Fig 10 Long profiles of submerged channels in the New Waterford area. Location of channels 2-5 shown in Figure 9, channels 1 and 6 in Fig 13.

of the channels are shown in Fig 10. They cut across the grain of the sea floor that is formed by 2 m-high ridges of gently folded Carboniferous rock. Seismic data show that they contain 3-6 m of sediment, and do not extend farther offshore under a Quaternary cover, but end at 45-m depth. Channel 1 (Fig 13) is $70 \mathrm{~m}$-wide and appears to be the extension of a small valley that runs inland $3.6 \mathrm{~km}$. Channel $2(140 \mathrm{~m}$ wide) lies off Lingan Beach and appears to be a continuation of a river that extends 8 $\mathrm{km}$ inland. Channel 3 may continue onshore as a short $(<2 \mathrm{~km})$ valley at Bridgeport (Fig 2). Channels 4-6 differ from channels 1-3 in that they begin far offshore, with no connection to onshore valleys (Figs 9, 10).

Grant $(1994 ; 1997)$ mapped submerged channels extending offshore from the Point Aconi area. Recent multibeam bathymetry shows a channel just north of Point Aconi that extends from a depth of $16 \mathrm{~m}$ to a depth of $\sim 40 \mathrm{~m}$, and seismic reflection profiles show that it contains up to $20 \mathrm{~m}$ of sediment. The channel appears to be the offshore extension of Aconi Brook, a river than extends up the middle of Boularderie Island (Fig 2). A meandering channel just south of this is incised into bedrock, with sidewalls 3-4 m deep. It extends from $10 \mathrm{~m}$ to 26-m depth, and contains an unknown thickness of sediment. Its onshore extension is a short valley a few kilometres long. Neither of these is the offshore extension of Little Bras d'Or Channel.

Because some of the channels begin offshore, have linear or convex thalwegs (line connecting the deepest points along a valley), and cut across Carboniferous strata, it is possible that they were initiated as sub-glacial meltwater channels. However, sub-glacial channels elsewhere in Atlantic Canada tend to be shorter, and non-meandering. The weight of evidence suggests the channels formed sub-aerially, probably when ice had retreated to the west, and spilled meltwater across an emergent shelf, as Grant (1994) showed. However, if they drained an ice front, the channels that begin offshore imply that the ice margin was seaward of the present coast and that relative sea level was low before the start of the Holocene. The channels off Point Aconi, as noted above, contain up to $20 \mathrm{~m}$ of sediment. We expect that a similar buried channel probably exists offshore from Little Bras d'Or Channel which, with its steep sidewalls, bears close resemblance to submerged channels in the Point Aconi area that have been surveyed with multibeam systems. 


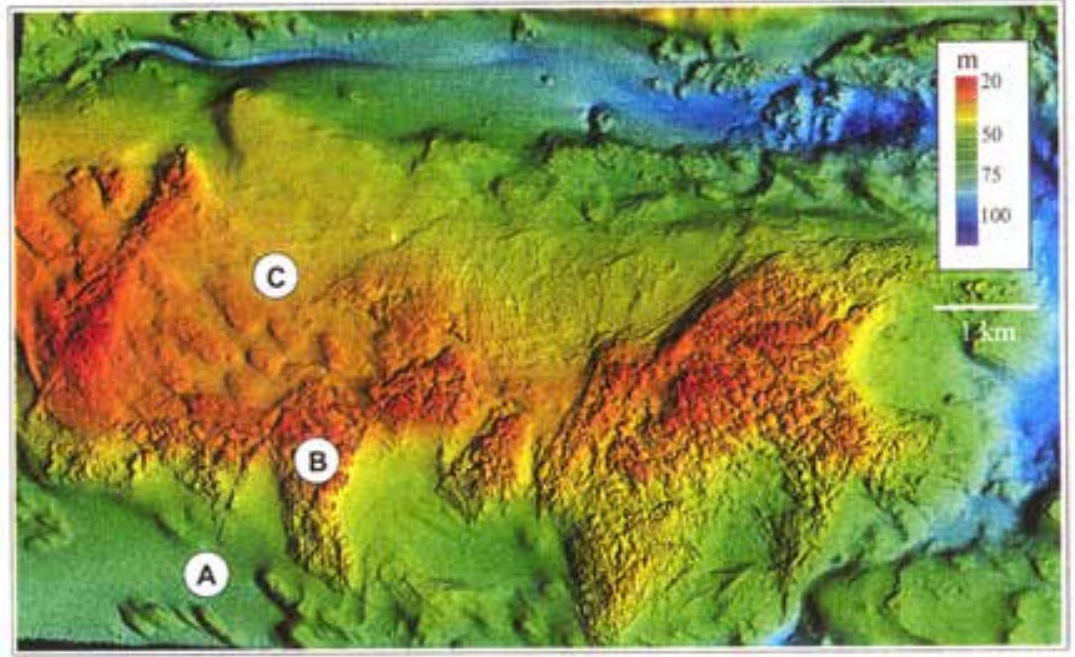

Fig 11 Coloured shaded-relief multibeam image of sea floor showing unmodified drumlins (A), rocky terrain (B) and truncated drumlins $(C)$ in the Isle Madame area. (See Fig 13 for location). Data courtesy of Mike Li and Ned King (Geological Survey of Canada - Atlantic).

Taylor et al. (1989) reported channels incised to about $30 \mathrm{~m}$ below sea level, and filled with $15 \mathrm{~m}$ of sediment, in St. Peter's Bay, near Isle Madame, on the southwest coast of Cape Breton Island. Multibeam imagery (Fig 11) of a shoal $10 \mathrm{~km}$ south of Isle Madame reveals drumlins on both north and south sides with NW-SE alignments similar to those onshore (Grant, 1988). They are unmodified below depths of $55 \mathrm{~m}$. Above this depth the terrain is rocky, with a cluster of truncated drumlins ('scars') at a depth of about $35 \mathrm{~m}$. The postglacial lowstand was no more than $55 \mathrm{~m}$ deep here. Other channels outside the Bras d'Or Lakes include $8 \mathrm{~m}$ deep channels incised to a depth of $34 \mathrm{~m}$ below sea level on Pomquet Banks, in St. Georges Bay west of Cape Breton Island (Shaw et al., 1995). An unconformity is developed in early postglacial sediments at $-34 \mathrm{~m}$ off the west coast of Cape Breton Island (Shaw et al., 1995).

Submerged river valleys and erosion surfaces within the Bras d'Or Lakes.

Unpublished results of a 1996 survey show that St. Patrick's Channel (Fig 2) contains a network of submarine channels that are commonly $100 \mathrm{~m}$ wide. They are incised 5-7 m into sediments with closely spaced, parallel, continuous, coherent internal reflections (having the appearance of Unit 3, Table I). The bases of the channels lie $17 \mathrm{~m}$ below the modern lake surface northeast of Little Narrows, and systematically deepen to a maximum of $29 \mathrm{~m}$ southwest of Baddeck. They are buried by 2-4 $\mathrm{m}$ of ponded, acoustically transparent Holocene mud of Unit 4, have no surface expression, and would therefore not appear on a multibeam image.

Unpublished multibeam bathymetry imagery from Denys Basin, in the western part of the main lake south of Barra Strait, shows a meandering river channel that extends eastward towards the middle of Bras d'Or Lake to a depth of at least $12 \mathrm{~m}$ (Paul, 2001); the hydrographic chart shows that this channel reaches a depth of at least $16 \mathrm{~m}$. Unlike those in the Baddeck area, the channels are not completely buried by the mud. 


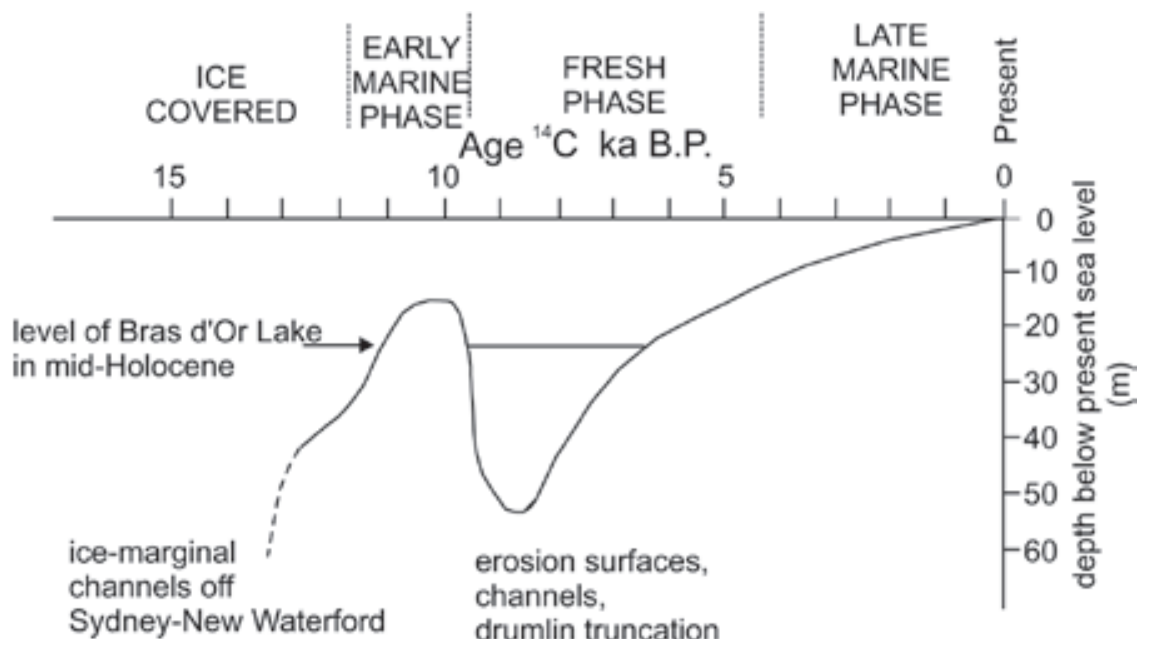

Fig 12 Model of changing sea and lake levels in the Bras d'Or Lakes region over the past 15000 years.

The seismic data illustrated in Fig 6 show the presence of unconformities cut at the top of Unit 2 (Table I) and in marginal deltaic sediments. They are commonly at depths of 25 to $22 \mathrm{~m}$, and testify to a sustained lake level at that depth. The data from the 1996 survey show that the seabed surrounding the basin just north of Cod Shoals (Fig 2) is flat, and constitutes an erosional unconformity. Acoustic reflections of Unit 3 are truncated at the sea floor to a maximum depth of $26 \mathrm{~m}$. Furthermore, several channels are incised into Unit 3 to depths of $26 \mathrm{~m}$. A major break of slope where the truncation zone is juxtaposed against Cod Shoals is at $-24 \mathrm{~m}$. Locally, shallower erosional features are seen at 18 to $20 \mathrm{~m}$ depth (Fig 6d).

\section{Geography of the Bras d'Or Lakes in the last 15,000 years}

On the inner Scotian Shelf, there is widespread evidence for high relative sea level as glacial retreat occurred between 18 and $12 \mathrm{ka}$. This was followed by a pronounced lowering of sea level some time in the 12 ka to 9 ka interval, and then gradually rising sea level until the present day. This resulted, for example, in the characteristic irregular ' $J$ ' shape of the sea-level curve for the inner shelf near Halifax (Stea et al., 1994). The data from the Bras d'Or Lakes suggest that a slightly different model is applicable to the evolution of the Bras d'Or Lakes (Fig 12), one with an early phase of low relative sea level.

In late glacial times, when south-eastern Cape Breton Island was covered with ice, valleys such as those in Fig 9 suggest that sea level was initially close to $-50 \mathrm{~m}$. As ice retreated, perhaps to the ice margin identified in the middle of St. Andrew's Channel (Fig 5a), meltwater continued to drain out through channels across the shelf, potentially deeply incising outlets such as Little Bras d'Or Channel. As ice retreated farther towards West Bay, and sea level rose, marine water eventually flooded into the Bras d'Or Lakes. 
Marine waters entered the Bras d'Or Lakes, probably through the channel at Little Bras d'Or, flooding first the main lake system and eventually the head of East Bay. The pollen stratigraphy at the head of East Bay suggests an age of about 10-9 ka for this incursion. The deltaic deposits in Fig $6 \mathrm{~d}$ may represent the limit of marine incursion at this time at about $-16 \mathrm{~m}$, a depth sufficient to bring sea water across the $-18 \mathrm{~m}$ sill that separates East Bay from the remainder of the paleo-lake system. This was followed by a fall in relative sea level that eventually cut off the Lakes from the sea once again.

In the early Holocene, following the fall of relative sea level that terminated the early marine phase, the stratigraphic evidence suggests a sustained lake level at about -25 $\mathrm{m}$ (Fig 13). This obviously requires that relative sea level outside the Lakes was deeper than $-25 \mathrm{~m}$, and also that the sill was deeper than today $(-8 \mathrm{~m})$. A large part of the

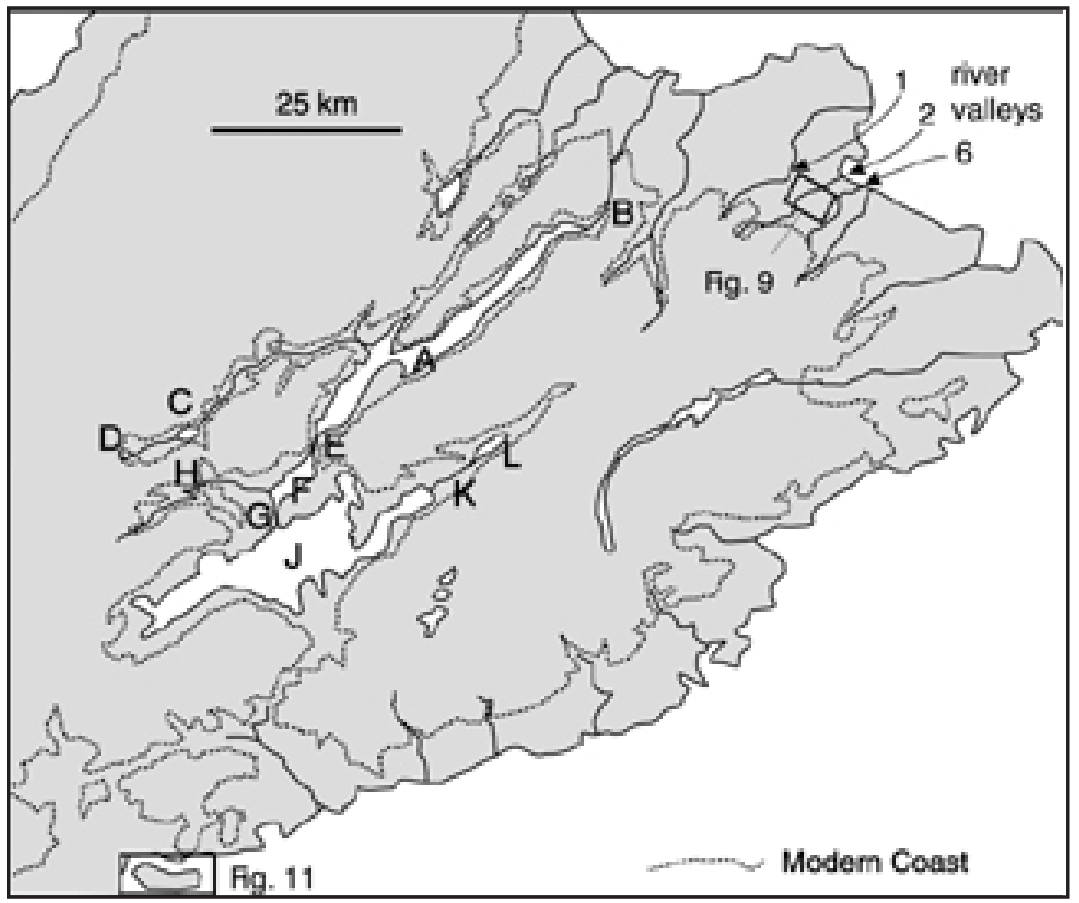

Fig 13 Suggested geography of the Bras d'Or Lakes at a -25 m water level. (A) a major part of the ancient lakes was north of Barra Strait; (B) Little Bras d'Or Channel, formerly an outlet for the lakes; (C) a small lake was located just west of Little Narrows; (D) location of a former lake in the Whycocomagh area; (E) a narrow part of the ancient lakes at Barra Strait; (F) a wider part of the lakes south of modern Barra Strait; (G) a narrow strait located on the modern Cod Shoals; $(\mathrm{H})$ the ancestral Denys River that drained into the ancient lakes; $(\mathrm{J})$ the largest part of the ancient lake system; $(\mathrm{K})$ a sill separating the main lakes from a small lake (L) in modern East Bay. The boxes show areas of multibeam bathymetry coverage. 1,2 and 6 are channels in the New Waterford area discussed in text and shown in Fig 9 and 10. 
ancient lake (Fig 13, A) was north of the modern Barra Strait, and drained out to the ocean via Little Bras d'Or Channel (B). St. Patrick's Channel was occupied by a river that reached the lake southeast of Baddeck and drained two lakes in Whycocomagh Bay: a larger lake at $-12 \mathrm{~m}$ immediately west of Little Narrows (C), and small lake just south of Whycogomagh at $-10 \mathrm{~m}$ (D). The large lake was extremely narrow at Barra Strait (E), widened to the south (F), and narrowed again on Cod Shoals $(\mathrm{G})$. The ancestral Denys River $(\mathrm{H})$ flowed east into the lake in this area. South of the narrows at Cod Shoal, the ancient lake (J) extended to both the northeast and southwest. The lake was very constricted in parts of East Bay, and probably ended south of Eskasoni (K) where a sill may have separated it from a smaller lake at the head of East Bay (L) at an elevation about -18 m (This lake was the site of core 16; Figs 2, 7). This mid-Holocene lake was eventually flooded by the sea as relative sea level rose again. The principal modern connection to the ocean is the $-8 \mathrm{~m}$ sill at Great Bras d'Or Channel, located on a morainal bank (Grant 1994). When this connection flooded, it is possible that the sinuous, hydraulically inefficient channel at Little Bras d'Or gradually shoaled at its landward end, perhaps due to flood-delta deposits. Depths for Little Bras d'Or Channel on CHS Chart 4367 are less than $5.5 \mathrm{~m}$, although there are indications of a channel $>11 \mathrm{~m}$ deep, perhaps the remains of a formerly deeper channel. The Little Bras d'Or outlet was probably the outlet for the mid-Holocene lakes and may have been the pathway for the incursion of marine water at about 5 to $4 \mathrm{ka}$ as sea level rose again.

Miller and Livingstone (1993) showed that relative sea level in Great Bras d'Or Channel rose during the last 4000 years, reaching $1.5 \mathrm{~m}$ below the modern level at $0.95 \mathrm{ka}$; the rate of sea level rise was less that that registered by tide gauges in the region (see rates in Shaw et al., 1993). It appears likely that cyclic fluctuations of eustatic sea level were superimposed on long-term crustal subsidence in Atlantic Canada during the last 3000 years, and that the modern rapid increase began c. 1600 AD (Shaw and Ceman, 1999).

\section{Conclusions}

The sediments on the floor of the Bras d'Or Lakes preserve an important record of the complex sequence of events that took place during the retreat of glacial ice from Cape Breton Island and during changing lake levels in the Holocene epoch. The thickness of sediment above glacial till shows that there was a step-like retreat of ice towards a late ice centre in the western part of the Bras d'Or Lakes. As ice retreated, a freshwater lake developed behind a sill (probably in Little Bras d'Or Channel). Marine incursion flooded this lake at 10 to $9 \mathrm{ka}$ and the water level may have risen to $-16 \mathrm{~m}$ before falling again. This falling early Holocene relative sea level resulted in the creation once again of freshwater lakes, with a prominent erosion surface at -25 m marking the lake level. These lakes were finally flooded by the sea at 4 to $5 \mathrm{ka}$.

It is evident that, despite the research that has taken place in the Bras d'Or Lakes, more needs to be done before we have a good grasp of the sequence of events since deglaciation. Ongoing work by Stea and his co-workers (Stea, 2001) may soon provide new insights into the chronology of deglaciation. A significant advance in understanding of relative sea-level and lake-level changes may come sooner rather than later, for much of the lake has recently been mapped using multibeam bathymetry systems, and more surveys will take place in 2001 (Paul, 2001). 


\section{Acknowledgements}

Much of the research described here was supported by the Geological Survey of Canada. This paper was reviewed by D.R. Parrott, P.J. Mudie, D.R. Grant and R.R. Stea. Mike Li and Ned King provided the multibeam data illustrated in Fig 11. Ken Paul allowed access to recent multibeam imagery of the Bras d'Or Lakes.

\section{References}

Boehner, R.C. 1985. Carboniferous Basin Studies, Salt, Potash, Celestite and BariteNew Exploration Potential in the Sydney Basin, Cape Breton Island. Mines and Mineral Branch Report of Activities 1984, Nova Scotia Department of Mines and Energy Report 85-1,153-164.

Calder, J.H. 1998. The Carboniferous evolution of Nova Scotia. In Lyell: the past is the key to the present. Eds by D.J. Blundell and A.C. Scott. Geological Society, London, Special Publication, 143: 261-302.

Canadian Hydrographic Service (CHS) 1990. Great Bras d'Or, St. Andrew's Channel and St. Ann's Bay, Chart 4277 (1:40,000), Edition 1983, Fisheries and Oceans Canada.

Canadian Hydrographic Service (CHS) 1991. Bras d'Or Lake, Chart 4279, 1:60,000, Edition 1986; Fisheries and Oceans Canada.

Canadian Hydrographic Service(CHS) 1993. Great Bras d'Or and St. Patrick's Channel, Chart 4278 (1:40,000), Edition 1986, Fisheries and Oceans Canada.

Cooper, C. 1993. Seabed disturbance from mobile fishing gear in the Bras d'Or Lakes; Project Summary, Industry Services and Native Fisheries, No. 44, October 1993; Department of Fisheries and Oceans, Halifax, N.S. 4 p.

de Vernal, A. and Jetté, H. 1987. Analyses palynologiques de sédiments holocènes du lac Bras d'Or (carotte 85-036-016P), île du Cap-Breton, Nouvelle-Écosse. In: Recherches en cours, Partie A, Commission géologique du Canada, Étude 87-1A, 11-15.

de Vernal, A. and Mott, R.J. 1986. Palynostratigraphie et paléoenvironnements du Pléistocene supérieur dans la région du lac Bras d'Or, île du Cap-Breton, Nouvelle Écosse. Canadian Journal of Earth Sciences, 23: 491-503.

de Vernal, A., Causse, C., Hillaire-Marcel, C., and Mott, R.J. 1986. Palynostratigraphy and $\mathrm{Th} / \mathrm{U}$ ages of upper Pleistocene interglacial and interstadial deposits on Cape Breton Island, eastern Canada. Geology, 14: 554-557.

Grant, D.R. 1988. Surficial Geology, Cape Breton Island, Nova Scotia; Geological Survey of Canada Map 1631A, 1:125,000 scale.

Grant D.R. 1994. Quaternary Geology, Cape Breton Island, Nova Scotia. Geological Survey of Canada Bulletin 482, Natural Resources Canada, Ottawa, 159 p.

Grant D.R. 1997. (Geological Survey of Canada, Ottawa). Personal communication.

Hillaire-Marcel, C. 1987. Composition isotopique du carbone organique des carottes du forage 85-036-016 dans le lac Bras d'Or, île du Cap-Breton, Nouvelle Écosse. In: Recherches en cours, Partie A, Commission géologique du Canada, Étude 871A, 859-864.

King, L.H. and Fader, G.B. 1986. Wisconsinan glaciation of the continental shelf, south-eastern Atlantic Canada. Geological Survey of Canada Bulletin, No. 363, $72 \mathrm{p}$. 
Keppie, J.D. 2000. Geological Map of the Province of Nova Scotia, Map ME 2000-1, 1:500,000; Nova Scotia Department of Natural Resources.

Livingstone, D.A. 1968. Some interstadial and postglacial pollen diagrams from eastern Canada. Ecological Monographs, 38: 87-125.

Lortie, G. 1987. Diatomées et evolution holocène du lac Bras d'Or, Nouvelle Écosse. In: Recherches en cours, Partie A, Commission géologique du Canada, Étude 871A, 859-864.

Lynch, D.W. 1995. Late Quaternary acoustic stratigraphy and glacial history of the Bras D'Or Lakes using seismic data and cores. B.Sc. Honours Thesis, Geology Department, Saint Mary's University, Halifax, Nova Scotia, 63 p. plus 2 maps.

Miller, R.F. 1997. Late -glacial (Allerød-Younger Dryas) Coleoptera from central Cape Breton Island, Nova Scotia, Canada. Canadian Journal of Earth Sciences, 34:247-259.

Miller, K.R., and Livingstone, D.A. 1993. Late-Holocene changes in sea level and environment on eastern Cape Breton Island, Nova Scotia, Canada. The Holocene, 3: 211-219.

Mott, R.J. and Stea R.R. 1993. Late Glacial (Allerød-Younger dryas) buried organic deposits, Nova Scotia Canada. Quaternary Science Reviews, 12: 645-657.

Paul, K. 2001. Personal communication.

Piper, D.J.W., Mudie, P.J., Aksu, A.E. and Skene, K.I. 1994. A 1 Ma record of sediment flux south of the Grand Banks used to infer the development of glaciation in southeastern Canada. Quaternary Science Reviews, 13: 23-37.

Roland, A.E. 1982. Geological background and physiography of Nova Scotia. The Nova Scotian Institute of Science, Halifax, N.S., 311 p.

Ryan, R.J. and Zentilli, M. 1993. Allocyclic and thermochronologic constraints on the evolution of the Maritimes Basin of eastern Canada. Atlantic Geology, 29: 187-197.

Shaw, J. and Ceman, J. 1999. Salt-marsh aggradation in response to late Holocene sea-level rise at Amherst Point, Nova Scotia. The Holocene, 9: 439-451.

Shaw, J., Taylor, R.B. and Forbes, D.L. 1993. Impact of the Holocene transgression on the Atlantic coastline of Nova Scotia. Géographie physique et Quaternaire, 47: 221-238.

Shaw, J., Forbes, D.L., Ceman, J.A., Asprey, K.A., Beaver, D.E., Frobel, D. and Jodrey, F. 1995. Marine geological surveys in Chedabucto and St. George's Bays, Nova Scotia, and Bay of Islands, Newfoundland. Cruise Report 94138. Geological Survey of Canada Open File 3230, 13 p., maps, figs.

Stea, R.R., Mott, R.J., Belknap, D.F., and Radtke, U. 1992. The pre-Late Wisconsinan chronology of Nova Scotia, Canada. IN: The last interglacial-glacial transition in North America. Eds. P.U. Clark and P.D. Lea, Geological Society of America, Special Paper 270, p.185-206.

Stea, R.R., Boyd, R., Fader, G.B.J., Courtney, R.C., Scott, D.B. and Pecore, S.S. 1994. Morphology and seismic stratigraphy of the inner continental shelf off Nova Scotia, Canada: Evidence for a $-65 \mathrm{~m}$ lowstand between 11,650 and 11,250 $\mathrm{C}^{14} \mathrm{yr}$ B.P. Marine Geology, 117: 135-154

Stea, R.R., and Mott, R.J. 1998. Deglaciation of Nova Scotia: Stratigraphy and chronology of lake sediment cores and buried organic sections. Géographie physique et Quaternaire, 41; 279-290.

Stea, R.R., Piper, D.J.W., Fader, G.B.J. and Boyd, R. 1998. Wisconsinan glacial and sea-level history of Maritime Canada and adjacent continental shelf: A correlation of land and sea events. Geological Society of America Bulletin, 110: 821-845. 
Stea, R.R. 2001. (Nova Scotia Dept. of Natural Resources, Halifax, N.S.) Personal communication.

Taylor, R.B., MacLean, B. and Beaver, D. 1989. Cruise Report 88-018 Phase 13 (G), M.V. Navicula; Southwest Cape Breton Island, Nova Scotia. Report, Atlantic Geoscience Centre, $31 \mathrm{p}$.

Vilks, G. 1967. Quantitative analysis of foraminifera in Bras d'Or Lakes. Bedford Institute of Oceanography Report 67-1, 84 p.

Wang, Y. and Piper, D.J.W. 1982. Dynamic geomorphology of the drumlin coast of southwest Cape Breton Island. Maritime Sediments and Atlantic Geology, 18: 1-27.

Received 1 March 2002 